\title{
Landscapes in transition: an analysis of sustainable policy initiatives and emerging corporate commitments in the palm oil industry
}

Rory Padfield, Simon Drew, Khadijah Syayuti, Susan Page, Stephanie Evers, Ahimsa Campos-Arceiz, Nagulendran Kangayatkarasu, Alex Sayok, Sune Hansen, Greetje Schouten, Martha Maulidia, Effie Papargyropoulou \& Mun Hou Tham

To cite this article: Rory Padfield, Simon Drew, Khadijah Syayuti, Susan Page, Stephanie Evers, Ahimsa Campos-Arceiz, Nagulendran Kangayatkarasu, Alex Sayok, Sune Hansen, Greetje Schouten, Martha Maulidia, Effie Papargyropoulou \& Mun Hou Tham (2016): Landscapes in transition: an analysis of sustainable policy initiatives and emerging corporate commitments in the palm oil industry, Landscape Research, DOI: 10.1080/01426397.2016.1173660

To link to this article: http://dx.doi.org/10.1080/01426397.2016.1173660

Published online: 24 May 2016.

Submit your article to this journal ¿

山 Article views: 80

View related articles $\asymp$

View Crossmark data $₫$ 


\title{
Landscapes in transition: an analysis of sustainable policy initiatives and emerging corporate commitments in the palm oil industry
}

\author{
Rory Padfield ${ }^{a}$ D , Simon Drew ${ }^{b}$, Khadijah Syayutia , Susan Page $^{c}$, Stephanie Evers $^{\mathrm{d}}$, \\ Ahimsa Campos-Arceiz ${ }^{\mathrm{e} *}$, Nagulendran Kangayatkarasu ${ }^{\mathrm{e}}$, Alex Sayok ${ }^{\mathrm{f}}$, Sune Hanseng, \\ Greetje Schouten ${ }^{\mathrm{h}}$, Martha Maulidiai, Effie Papargyropoulou and Mun Hou Tham ${ }^{\mathrm{a}}$
}

\begin{abstract}
aMalaysia Japan International Institute for Technology, Universiti Teknologi Malaysia, Kuala Lumpur, Malaysia; ${ }^{\mathrm{b}}$ Geography, Politics \& Sociology, Newcastle University, Newcastle upon Tyne, UK; 'Department of Geography, University of Leicester, Leicester, UK; ${ }^{d}$ School of Biosciences, The University of Nottingham Malaysia Campus, Semenyih, Malaysia; 'eschool of Geography, The University of Nottingham Malaysia Campus, Semenyih, Malaysia; fInstitute of Biodiversity and Environmental Conservation, Universiti Malaysia Sarawak, Kota Samarahan, Malaysia; IUTM Palm Oil, Universiti Teknologi Malaysia, Kuala Lumpur, Malaysia; ' $P$ Public Administration and Policy Group, Wageningen University, Wageningen, the Netherlands; 'School of Geography, Planning and Environmental Management, University of Queensland, Brisbane, Australia
\end{abstract}

\begin{abstract}
The recent Southeast Asian haze crisis has generated intense public scrutiny over the rate, methods and types of landscape change in the tropics. Debate has centred on the environmental impacts of large-scale agricultural expansion, particularly the associated loss of high carbon stock forest and forests of high conservation value. Focusing on palm oil-a versatile food crop and source of bioenergy - this paper analyses national, international and corporate policy initiatives in order to clarify the current and future direction of oil palm expansion in Malaysia and Indonesia. The policies of 'zero burn', 'no deforestation' and 'no planting on peatlands' are given particular emphasis in the paper. The landscape implications of corporate commitments are analysed to determine the amount of land, land types and geographies that could be affected in the future. The paper concludes by identifying key questions related to the further study of sustainable land use policy and practice.
\end{abstract}

\section{KEYWORDS}

Palm oil; environmental policy; corporations; diffusion of innovation theory; deforestation; peatlands; Malaysia; Indonesia

\section{Introduction}

In a period of less than a year between June 2013 and April 2014, the rate, methods and types of landscape change in Southeast Asia came under intense public scrutiny (Forsyth, 2014). The catalyst for this scrutiny was two major episodes of jerebu (or 'haze') across the region: in June/July 2013 and in February/March 2014. Defined as the weather phenomenon that leads to an atmospheric visibility of less than $10 \mathrm{~km}$ due to suspended solid or liquid particles, smoke and vapour in the atmosphere (Xiao et al., 2011), haze in Southeast Asia is commonly caused by the burning of forest and peat soils to make way for agricultural development (Centre for International Forestry Research [CIFOR], 2013). In 
early 2014, the haze was intensified by an unusually long dry spell of weather and Indonesia, Malaysia, Singapore, Brunei, southern Thailand and parts of western Philippines were affected. Major disruption ensued including closure of schools, an increase in haze-related ill health, disruption of airline schedules and adverse impacts on local businesses and tourism (Emilia, 2014).

At the heart of the Southeast Asian trans-boundary haze crisis is the issue of large-scale landscape transformation. Forests and peat catchments have been targeted for logging and subsequent planting of agricultural commodities, primarily oil palm (Tacconi, Jotzo, \& Grafton, 2007). The expansion of oil palm in these regions is driven by lucrative financial returns as economies seek to maximise their natural advantage in an increasingly competitive global economy. Huge demand for palm oil and its derivative products from Europe, North America and in particular China and India drives continued landscape clearance and transformation in the tropics. Oil palm plantations have been developed across much of Southeast Asia, and more recently in Latin America, and West and Central Africa (Butler \& Laurance, 2009). Expansion in these countries includes areas of high ecological and environmental value, such as primary and secondary forests and peatland catchments. This situation presents a considerable challenge to landscape policy-makers - how to increase the production of food commodities, such as palm oil, whilst simultaneously protecting and enhancing the ecosystems and landscapes which support the production system and provide wider ecosystem services, such as biogeochemical cycling, carbon storage, biodiversity, water, recreational and cultural identities (Swaffield \& Primdahl, 2014).

In May 2014, many of the world's largest resource companies (Sime Darby, Wilmar International, APRIL, Olam International and Unilever) and financial institutions (Citi Bank, HSBC and Credit Swisse) convened in Singapore ${ }^{1}$ to defend their position on recent practices and underscore their commitment to existing sustainability initiatives, such as the Roundtable on Sustainable Palm Oil (RSPO). Initiated by businesses and non-governmental organisations (NGOs), the RSPO aims to transform the palm oil industry by advancing the production, procurement, finance and use of sustainable palm oil products. To this end, the RSPO developed principles and criteria for the sustainable production of palm oil as well as an accompanying certification scheme (RSPO, 2013).

With the aim of contributing towards current debates on sustainable land use policy and practice in Southeast Asia, this paper summarises current national and international policy initiatives for palm oil production in Malaysia and Indonesia, the two biggest palm oil-producing countries in the world. Information on the current policies and plans for expansion were examined via a review of three secondary data sources: first, a review was undertaken of national-level plans as reported in forestry, biodiversity and agricultural government policy documents in both countries. These documents were examined for any indication (intent or explicit plans) of future palm oil expansion plans as well as conservation of forested areas. Second, national-level agricultural and forestry statistics held by the Food and Agriculture Organisation (FAO) (www.fao.org) were sourced to determine current levels of forest and palm oil coverage. In the case of Malaysia, information was also obtained via discussions with officials in the Malaysian Palm Oil Board (MPOB) and the Ministry of Plantations, Industries and Commodities to support the data collection process. Third, a review of published scientific articles sourced within the Thompson Reuters Web of Science database and reports published by research institutes (CIFOR) in related fields was undertaken to complement analysis of the two aforementioned data sources. Keywords searched for included:'Iand use change','government/industry policy,' 'Southeast Asia', 'palm oil', 'deforestation' and 'peatlands'.

Next, an analysis was undertaken of corporate sustainability pledges made by palm oil firms in Malaysia and Indonesia, with a specific focus on three key policies:'zero burn','no deforestation' and 'no planting on peatlands'. Firms identified for policy review included the 10 largest companies operating in Malaysia and Indonesia in terms of the size of planted palm oil estates and all RSPO member growers operating in the two countries. In December 2014, there were 78 RSPO member palm oil grower companies: 25 from Malaysia, 46 from Indonesia and 7 from Singapore. In order to analyse the relationship between size of company and policy commitments to sustainable practices, each of the 78 companies was classified by total plantation area as follows: Class I: less than 10,000 hectares; Class II: 10,000-50,000 hectares; Class III: 50,000-100,000 hectares; and Class IV: greater than 100,000 hectares. 
Sourcing of corporate policies was achieved by examining publicly available corporate reports and/or webpages published within individual company websites. Such reports were typically located within 'Corporate Policies,' 'Corporate Profile,' 'Sustainability' or similarly named sub-headings.

Finally, to elucidate the landscape implications of these pledges, the amount, type and location of land potentially affected in Indonesia and Malaysia were identified and mapped out to allow geographic comparison. This aspect of the research focused on the areas and locations of primary forests, secondary and selectively logged forests and peatland forests within both countries from state- and national-level governmental reports and statistics. The paper concludes by identifying a number of key questions related to the further study of sustainable land use policy and practice. All secondary sources of information analysed in this research, including corporate websites, government policy documents and forestry and peatland statistical sources, are provided in the online supplementary information.

\section{A summary of the palm oil sustainability challenge}

Malaysia and Indonesia's comparative advantage for palm oil expansion-the ability to draw on lowcost labour from the region, available land and climatic conditions - and existing land use policies have led to large-scale acquisition of land by state and federal bodies. Beginning in the 1950s, governmentdriven policies in both countries led to wide-scale conversion of previously logged forests, primary and secondary forests, rubber and other plantations (McCarthy \& Cramb, 2009). The Federal Land Development Authority (FELDA) scheme in Malaysia is an example of the type of land acquisition capabilities used for plantation expansion. Established in 1956 as a government body to advise, finance and coordinate various state land settlement schemes, by 1998, FELDA had acquired 841,305 hectares of land $-80 \%$ of which was used for oil palm (Sutton, 2001).

Wicke, Sikkema, Dornburg, and Faaij (2011) estimate that between 1975 and 2005 the total land expansion for oil palm production reached 9 million hectares (Mha), 4 Mha in Malaysia and 5 Mha in Indonesia. In terms of deforestation during this period, Indonesia had forest losses of 40 Mha (equivalent to a $30 \%$ reduction in forest land) whilst 5 Mha of forest was lost in Malaysia (equivalent to a $20 \%$ reduction in forest land) (Wicke et al., 2011). Increasingly, plantations are being established on carbonrich peat soils. In 2010, they covered 3.1 Mha (20\%) of peatlands in Peninsular Malaysia, Sumatra and Borneo, but with a projected expansion to 6-9 Mha by the year 2020 (Miettinen et al., 2012). The vast expansion of the oil palm crop has established Malaysia and Indonesia as the two largest palm oilproducing countries in the world.

As information on the scale of oil palm expansion in Southeast Asia has become increasingly available, opposing viewpoints have emerged as to the long-term environmental, economic and social sustainabilities of such a development. Those opposing wide-scale expansion of palm oil stress the ecological impacts of past conversion, namely the loss of high carbon stock forest (HCS) and forests of high conservation value (HCV). Studies have shown that large-scale biodiversity loss accompanies palm oil conversion of natural forests (Fitzherbert et al. 2008; Foster et al., 2011; Koh \& Ghazoul, 2008) as well as contributing to long-term increase in atmospheric carbon dioxide, particularly where plantations are established on peat (Hooijer et al., 2010). Sustainability concerns are also associated with palm oil production at plantations and mills, including environmental impacts from the open lagoon treatment and discharge of palm oil mill effluent (Hansen et al., 2015), and fertiliser and pesticide use (Choo et al., 2011).

Conversion of tropical peatlands to oil palm has been a point of contention for environmentalists as the biodiversity and considerable carbon store potential have become better understood (Moore et al., 2013; Page, Rieley, \& Banks, 2011; Padfield et al., 2014). Many NGOs focus on the need to increase yields in smallholder production to avoid further expansion of palm oil planted area. Social impacts of oil palm development, such as land tenure (Cramb \& Sujang, 2011) and plantation worker health and safety, have also been highlighted (Pye, Daud, Harmono, \& Tatat, 2012)

Sustainability concerns have been raised regarding the different scales of production. Smallholder planters, typically family-based enterprises producing palm oil from less than 50 ha of land (RSPO, 2006), 
make up a considerable proportion of total production of palm oil, 38\% in Malaysia (MPOB, 2013) and $33 \%$ in Indonesia (Vermeulen \& Goad, 2006). However, due to weak economies of scale, such planters often purchase the cheapest and least sustainable chemical products and undertake slash and burn land clearing techniques (Vermeulen \& Goad, 2006), the latter contributing towards the regional haze crisis. Indeed, a study of the 2006 peat fires established that $59 \%$ of the fire emissions from Sumatra and $73 \%$ of the emissions from Kalimantan originated outside timber and oil palm concession boundaries, indicating smallholder and mid-scale landowner responsibility (Marlier et al., 2015).

Whilst actors opposed to the wide-scale expansion of oil palm largely focus on deforestation and biodiversity losses (Lucas, 2011; Pierce, 2008), supporters of palm oil emphasise the significant socioeconomic benefits provided by the industry. Indonesian and Malaysian actors have a strong focus on the significant employment opportunities (Malaysian Palm Oil Board (MPOB), 2011) and how industry contributes to poverty alleviation (Schouten \& Glasbergen, 2011). Furthermore, palm oil yields by far exceed those of other vegetable oil crops, making it the most efficient oil crop on the market (Padfield \& Hansen, 2010). The average palm oil yield is 4.25 tonnes hectare ${ }^{-1}$ year $^{-1}$ which compares favourably against rapeseed (1.3), sunflower (0.46) and soyabean (0.4) (Oil World, 2009).

\section{Palm oil policy developments}

We analyse two broad categories of policy pertinent to the expansion of palm oil in Southeast Asia: (i) national and international policies; (ii) palm oil corporate policy initiatives.

\subsection{National and international policies}

Analysis of national policy developments in Indonesia and Malaysia indicates a number of changes towards a more 'sustainable oil palm expansion strategy' —allowing continuing development of the industry on areas such as degraded or previously converted land whilst retaining areas of high ecological value. In Malaysia, since the establishment of the National Forestry Act (1984), 14.5 Mha have been designated as protected forest reserves and permanent forest estates (Government of Malaysia, 2014a). At the 1992 Rio Earth Summit and reiterated in the 5th National Report to the Convention on Biological Diversity (CBD) (Government of Malaysia, 2014a), Malaysia pledged to maintain at least $50 \%$ of its land area under forest and tree cover in perpetuity. ${ }^{2}$ Whilst such a commitment places Malaysia above the world average in terms of percentage forest cover remaining (Food \& Agriculture Organisation [FAO], 2011), the need for land use change is explicitly recognised as an important factor in the country's continued development. The CBD (2014a: 16) states that 'with regards to land capability and overall land use, it is noted that there is a need for further development to meet the requirements of a growing population and the country's socio economic development agenda'.

Further to this, Malaysia's palm oil industry is guided by the National Commodities Policy (NCP) 2011-2020. The NCP envisages the planted area for oil palm from 2011 to 2020 to increase at a rate of $1.6 \%$ annually (Government of Malaysia, 2014b). Discussions with officials from Ministry of Plantations, Industries and Commodities and MPOB revealed that in Peninsular Malaysia, there is a Cabinet directive to only allow conversion of other agricultural land for oil palm plantation with no conversion of forested areas (N. Karim \& N. Ibrahim, personal communication, June 17, 2014). This marks a departure from past policy directives which allowed oil palm conversion on logged-over land zones (Varkkey, 2012), including areas known as 'state forest reserves'. These forests were previously logged for timber prior to conversion to oil palm, but still contain HCS (Hansen, Olsen, \& Ujang, 2014). In recent years, more than $50 \%$ of new oil palm plantations in Malaysia were converted from state forest reserve with $25 \%$ being former rubber plantations and just under $20 \%$ from other previous land uses (Hansen et al., 2014).

Indonesia has initiated a number of new policies to address land use change with a focus on reducing the environmental impact of the palm oil industry. This includes the Law on Prevention and Eradication of Forest Destruction (Government of Indonesia, 2013a) and the National Action Plan for GHG Emissions Reduction (Government of Indonesia, 2011), both supporting policy pathways to prevent deforestation 
and reduce emissions in the forestry sector. A further initiative was the 2011 moratorium on forest licences over 69 million hectares (Mha). This policy was established to suspend haphazard forest exploitation and, in effect, curtail further oil palm expansion (Murdiyarso, Dewi, Lawrence, \& Seymour, 2011). This was part of a bilateral 'REDD + Readiness' programme (see below) of governmental reform and forest conservation (Sloan, 2014). Studies of the impact of Indonesia's forest moratorium identify a number of processes, transparencies and governance weaknesses that undermine its original goal (Murdiyarso et al., 2011; Sloan, 2014). Sloan (2014) argues that from a total 69 Mha covered under the moratorium, only 12-22 Mha were afforded new protection from licencing and a further 5.5 Mha overlap with forest licences. The extent of the area actually protected under the moratorium is unclear which, critically, leaves open the potential for further deforestation in the future.

Private transnational governance initiatives have also heavily shaped the landscape policy arena in Malaysia and Indonesia. The RSPO provides a framework for sustainable practice around a set of principles and key criteria. Companies can achieve certification if they meet specific standards on such issues as planting, milling and waste management (RSPO, 2013) and, in 2012, sustainable palm oil was $15 \%$ of total production (RSPO, 2012).

Critics of RSPO certification have identified a number of weaknesses which present challenges for the wide-scale adoption and implementation of the standard, and in turn, the prospects for sustainable land use change. For instance, the RSPO principles and criteria require that an HCV assessment is made of an area before it is developed into a palm oil production area. If the area is classified as HCV, it has to be preserved according to the RSPO standard. However, the conservation of an HCV area can be in conflict with Indonesian regulation. The Indonesian Government gives a concession to a company to develop a designated area within a specific time frame. Producers fear that if they don't develop (part of) the area, because it is classified as HCV under the RSPO, the Indonesian Government will transfer the concession to another company (Schouten \& Glasbergen, 2012).

A further criticism against the RSPO is that it legitimises palm oil expansion into secondary and peatland forests. Whilst RSPO members have to ensure that forests are assessed for HCV before new plantings (RSPO, 2013), RSPO certification allows clearance of any forest not identified as primary or HCV forests. Such a distinction is significant since the majority of the remaining forest available to the industry in Malaysia and Indonesia is secondary, selectively felled or degraded and may not be identified as HCV and, therefore, is at risk from conversion. Whilst not primary, these forests still retain high biodiversity and provide other ecosystem services including carbon sequestration and storage (Gibson et al., 2011). Despite strengthening the criteria for planting in HCV lands-there is a voluntary guideline for members to report greenhouse gas (GHG) emissions from conversion-the planting of oil palm on peatland forests is also accepted and plantations can still be RSPO-certified (Greenpeace, 2013b). Planting oil palm on tropical peatlands is associated with the highest potential for carbon losses (Goldstein, in press; Miettinen, Wang, Hooijer, \& Liew, 2011; Moore et al., 2013; Takakai et al., 2006).

Other weaknesses include poor enforcement (Greenpeace, 2013b), difficulty in smallholder participation and dominance of large companies (von Geibler, 2013) and contestation of RSPO legitimacy by local actors (Marin-Burgos, Clancy, \& Lovett, in press). Further, country-specific sustainable certification standards have been launched in both countries: the Malaysian Sustainable Palm Oil (MSPO) standard and the Indonesian Sustainable Palm Oil (ISPO) standard (United Nations Development Programme [UNDP], 2012; ). These country-specific standards are to be implemented independently and separately of the existing RSPO certification framework for sustainable palm oil. The use of the MSPO standard is voluntary (MSPO, 2013), whilst ISPO standard is mandatory for all local firms and verified through third-party auditing. The ISPO has the aim 'to improve the competitiveness of Indonesian palm oil on the global market and contribute to the objective set by the President of the Republic of Indonesia to reduce GHG emissions and draw attention to environmental issues' (ISPO, 2014). Because MSPO and ISPO are relatively young standards, their effect on the wider policy landscape is still unclear.

Other international policy initiatives with potential long-term impacts on landscape change in Malaysia and Indonesia include the Reducing Emissions from Deforestation and Forest Degradation in Developing Countries (REDD+) scheme, the Forest Carbon Partnership Facility (FCPF) and Forest 
Investment Programme (FIP), the latter two hosted by the World Bank. The REDD + scheme has made advances following the forest moratorium in Indonesia. In ongoing negotiations, the Indonesian Government stands to gain US\$1 billion in REDD + payments if proof is shown that the government has successfully conserved forest land and reduced carbon emissions (Singapore Institute of International Affairs, 2014).

Despite the existence of various national and international policies and legal frameworks to manage land use change and protect the remaining forest resources, deforestation continues to occur and apparently, in some cases, illegal conversion of protected forests to oil palm plantations (The Star, 2014). Varkkey (2012) argues that patronage politics_-'a form of domination that is used by modern political and economic elites to channel resources for their own benefit' (Gunes-Ayata, 1994, pp. 17-26)—plays a significant role in the high levels of unauthorised activity in illegal licensing and land clearing in the Indonesian and Malaysian palm oil industries. Furthermore, different national and provincial priorities can also play a part. In Indonesia, although the conversion of primary forests into plantations must theoretically be approved by the Ministry of Forestry, regional governments rarely comply with such regulations (Varkkey, 2012).

\subsection{Palm oil corporate policy initiatives}

On 5 December 2013, the world's largest producer and trader of palm oil, Wilmar International, made a commitment to 'no deforestation', 'no planting on peat' and 'no exploitation' (Wilmar International, 2013). Alongside Wilmar's existing commitments to sustainable certified palm oil via the RSPO, the new policy included a commitment to no further planting on HCS forests, forests of HCV or peat soil, regardless of peat depth, as well as provisions to progressively reduce GHG emissions on existing plantations (Wilmar International, 2013). The policy extends to all operations within the supply chain, including subsidiaries and third parties from whom Wilmar purchase. Not only does such a commitment help reassure investors and associated stakeholders along the supply chain concerned about Wilmar's past track record of deforestation (Stanford, 2014), it sends a clear message to environmental groups who have been calling for a change in their land development policies. One of Wilmar's biggest critics, Greenpeace International, applauded the new policy stating that it 'could be a landmark win for the world's forests and the people that depend on them for their livelihoods' (Greenpeace, 2013a). It was also suggested that it could lead to a'green revolution' in the food production industry (Poynton, 2014).

Wilmar is not the first company to make a public statement on the issue of deforestation and the planting on peatlands. ${ }^{3}$ In 2008, the largest Malaysian palm oil producer, Sime Darby, introduced a policy prohibiting the development of new plantations on deep peat (peat greater than three metres in depth) (Sime Darby, 2016). In 2013, this policy was extended to all new developments on peat irrespective of peat depth (Sime Darby, 2016). In 2009, the second largest Singaporean producer of palm oil company, Golden Agri-Resources (GAR), launched its own policy of no new development on peatlands, HCV or HCS forests (GAR, 2012). In 2014, GAR extended this policy to all downstream aspects of their business - mirroring the approach taken by Wilmar-to include all third-party agents in their supply chain. Since Wilmar's policy statement in December 2013, five of Southeast Asia's largest producers of palm oil have made public commitments to'no deforestation' and four of these companies have also made commitments to'no planting on peatland'. This also includes the Sustainable Palm Oil Manifesto, a commitment by five of the largest palm oil companies which states a provision to'accelerate the journey to no deforestation through the conservation of HCS forests and the protection of peat areas regardless of depth' (High Carbon Stock Study, 2014). Figure 1 illustrates the adoption of sustainability policies by the top-10 palm oil-producing companies from Malaysia, Indonesia and Singapore between 1985 and 2014. Whilst nearly half of the companies made policy commitments to zero burning during the mid-2000s (a likely response to the 1997 haze crisis), the number of pledges to no deforestation and no peatland policies have increased sharply from 2010/2011.

Analysis of sustainability policy adoption by the medium and smaller companies in the industry reveals a different trend. Research was undertaken to find evidence of online policy statements or references 


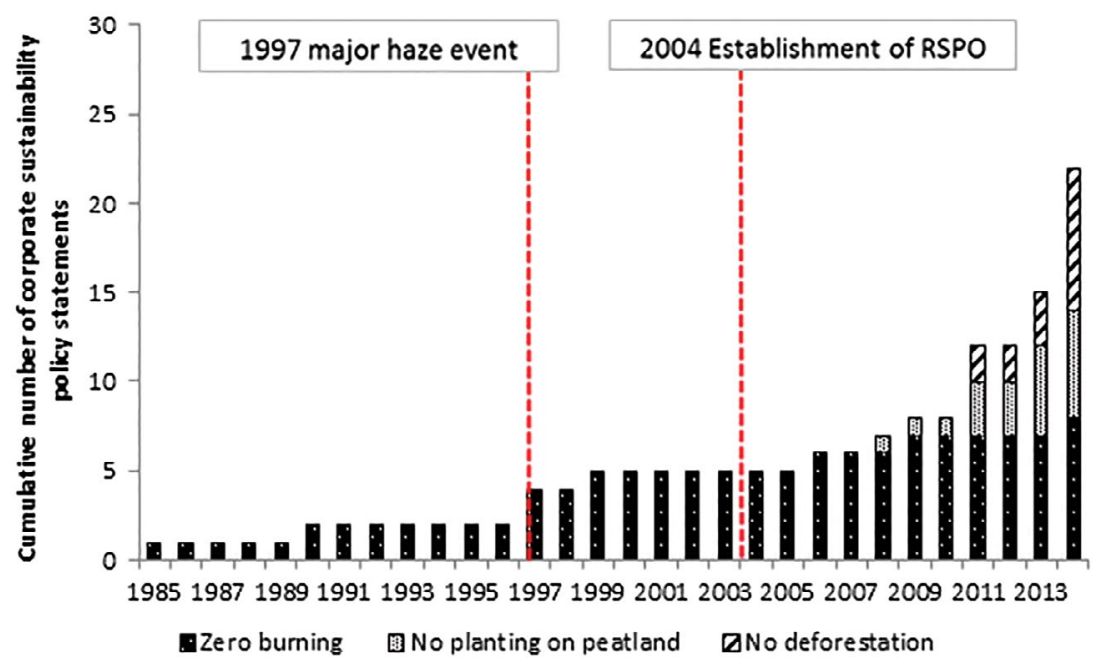

Figure 1. Adoption of policies pertaining to 'zero burning,' 'no planting on peatland' and 'no deforestation' by the 10 largest oil palm producers operating in Malaysia and Indonesia. Source: Corporate websites of palm oil companies.

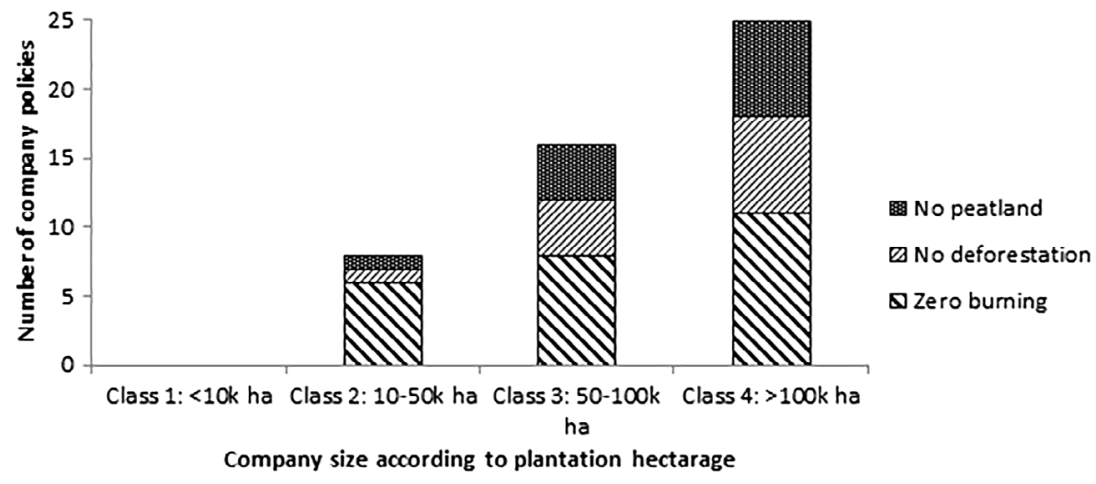

Figure 2. Policy pledges to 'zero burning,',no deforestation' and 'no planting on peatland' by palm oil growers according to the size of plantation (Class 1: <10 k ha, Class 2: 10-50 k ha, Class 3: 50-100 k ha, Class 4: >100 k ha) from Malaysia (25 grower companies), Indonesia (46 grower companies) and Singapore (6 grower companies) with RSPO-approved membership. The figure is based on all RSPO palm oil grower members from the three named countries as reported in December 2014. Source: RSPO (2014) and palm oil company websites.

to the adoption of practices related to'zero burn','no deforestation' and 'no peatland planting' amongst companies with RSPO membership. As shown in Figure 2, there is a clear positive relationship between policy adoption and size of plantation holding. The zero burn policy has the largest representation across class sizes two, three and four, whilst class size one has no recorded commitments to any of the three policies. Thus, in terms of the specific issues of deforestation and peatland planting, there appears to be an emerging polarisation of the palm oil industry: large companies (ie with plantations larger than 50 thousand hectares) making public demonstrations of their sustainability credentials and small- and medium-sized companies (plantations less than 50 thousand hectares) with less tangible and visible (if any) commitments to sustainability. Whilst it is acknowledged that some companies may practice the policies without having a formal statement clearly visible on their website, it is also assumed that most would aim to publicly present their positive environmental practices (or intent to practice).

Examined from the perspective of diffusion of innovation theory (Rogers, 1962) (which posits how over time, an idea or product gains momentum and diffuses through a specific population or social system), 'innovators' or 'early adopters' groups appear to be drawn exclusively from the largest oil palm 
companies. The adoption of such policies by other players, especially after 2010 , indicates a genuine diffusion of policy amongst more of the largest companies. The diffusion of sustainability policy in the palm oil industry is consistent with research from different industries, sectors and geographies where policy innovators tend to be from firmly established market leaders or where there is a drive to meet international standards (Christmann \& Taylor, 2001; Papargyropoulou, Padfield, Harrison, \& Preece, 2012; Zhu, Cordeiro, \& Sarkis, 2012).

Similarly, it is plausible to argue that the largest palm oil companies are making explicit public policy statements on sustainability aspects in order to gain or maintain access to European and North American markets where high levels of sustainability certification are demanded and where importance is placed on maintaining brand credibility to environmentally savvy supply chains, consumers and investors. Conversely, it can be argued that the medium- and smaller sized companies are less driven to demonstrate their sustainability credentials since many of them are targeting local and regional markets in Southeast Asia, China and India, where there is currently less demand for sustainability and greater emphasis on price competitiveness.

The challenge faced in building consensus amongst all stakeholders, including medium and small planters and those located in largely peatland areas, is illustrated by the Sarawak Oil Palm Planters Owners Association's (SOPPOA) response following Wilmar's announcement to withdraw from proposed peatland planting in East Malaysia. SOPPOA argues that the policy is 'discriminatory to oil palm planters in Sarawak and damaging to the state's government's development plan of achieving 3 million hectares of oil palm' (Sarawak Report, 2014). SOPPOA's concerns have also been supported by the Malaysian Ministry of Plantations and Commodities stating that a boycott of palm oil from peat soil should be regarded as 'inhumane and goes against any policy for the wellbeing of people to elevate themselves from poverty, especially rural native communities' (Malaysian Palm Oil Council [MPOC], 2014).

\section{Implications for tropical landscape change: the potential for forest and peatland protection}

Developments in palm oil-related policy at international, national and corporate levels in the past decade indicate a level of policy convergence in terms of the collective ambition to achieve a sustainable landscape transformation strategy for Southeast Asia. Notwithstanding policy implementation challenges faced by stakeholders involved in land use governance (authorities and enforcement agencies, growers, NGOs, etc.), it is pertinent to analyse the amount, type and location of land potentially

Table 1. Land types and areas (Mha) in Indonesia and Malaysia affected by palm oil corporate policy initiatives.

\begin{tabular}{|c|c|c|c|c|}
\hline Country & Region & Primary forests (Mha) & $\begin{array}{l}\text { Secondary and } \\
\text { selectively logged } \\
\text { forests (Mha) }\end{array}$ & $\begin{array}{l}\text { Peatland forests } \\
\text { (Mha) }\end{array}$ \\
\hline \multirow[t]{4}{*}{ Malaysia } & & $3.82(\mathrm{a})$ & $17.32(a, b, c)$ & $0.57(\mathrm{e})$ \\
\hline & Peninsula Malaysia & $\mathrm{n} / \mathrm{a}^{*}$ & $3.88(\mathrm{a})$ & $0.23(\mathrm{e})$ \\
\hline & Sabah & $1.0(b)$ & $3.47(b)$ & $0.03(\mathrm{e})$ \\
\hline & Sarawak & $n / a^{*}$ & $9.97(c)$ & $0.31(\mathrm{e})$ \\
\hline \multirow[t]{8}{*}{ Indonesia } & & $46.71(d)$ & $51.35(d)$ & $10.18(e)$ \\
\hline & Sumatra & 4.0 (d) & $9.97(\mathrm{~d})$ & $1.81(\mathrm{e})$ \\
\hline & Kalimantan & $9.71(d)$ & $18.77(d)$ & $2.4(\mathrm{e})$ \\
\hline & Indonesian Papua & $25.93(d)$ & $7.47(d)$ & $5.97(\mathrm{e})$ \\
\hline & Sulawesi & $5.05(\mathrm{~d})$ & 5.19 (d) & Negligible \\
\hline & Jawa & $0.33(d)$ & $3.67(d)$ & $\mathrm{n} / \mathrm{a}^{*}$ \\
\hline & Bali Nusatenggara & 0.69 (d) & 1.99 (d) & $\mathrm{n} / \mathrm{a}^{*}$ \\
\hline & Maluku & $1.0(d)$ & 4.29 (d) & $\mathrm{n} / \mathrm{a}^{*}$ \\
\hline Total & & 50.53 & 68.67 & 10.75 \\
\hline
\end{tabular}

(a) Government of Malaysia (2012);

(b) Sabah Forestry Department (2012);

(c) Sarawak Forest Department (2014);

(d) Government of Indonesia (2013b);

(e) Joosten, Tapio-Biström, and Tol (2012);

${ }^{*} \mathrm{n} / \mathrm{a}=$ no data available or data reliability issues. 
affected by the recent policy developments. Table 1 shows the amount of primary forests, secondary and selectively logged forests and remaining peatland forests as found in Malaysia (Peninsula Malaysia, Sabah and Sarawak) and Indonesia (Sumatra, Kalimantan, Sulawesi, Indonesian Papua, Jawa, Maluku and Bali Nusatenggara). These figures represent the potential area of land protected (land no longer'available' for development) from further palm oil cultivation by those companies who have made recent policy pledges to sustainability. More specifically, primary forests (or'HCV forest' or' $\mathrm{HCS}$ ' as a proxy of primary forests) and peatlands are the land types explicitly addressed by the corporate policy commitments to 'no deforestation' and 'no planting on peatland'. In theory, even if such land types become available for development, companies who have made the policy commitments have effectively ruled themselves out from utilising this land.

In Table 1, primary forest is defined as naturally regenerated forest of native species, where there are no clearly visible indications of human activities and the ecological processes are not significantly disturbed. Secondary and selectively logged forest refers to naturally regenerated forests where there are clearly visible indications of human activities. Peatland forest refers to pristine, slightly degraded, moderately degraded and heavily degraded peatland forests with no oil palm or commercial plantations cultivated. Indonesia has the most primary forests (46.7 Mha), peatland forests (10.18 Mha) and secondary and selectively logged forests (51.4 Mha). Within Indonesia, the province of Indonesian Papua has the largest amount of both primary forests (25.93 Mha) and peatlands (5.97 Mha) followed by Kalimantan ( 9.7 Mha of primary forests and 2.4 peatlands) and Sumatra (4 Mha primary forests and 1.81 peatlands) (Figure 3). The potential areas of primary and peatland forests saved in Malaysia are smaller but still comprise a total of 3.82 Mha of primary forests, 0.57 Mha of peatlands and 17.32 Mha of secondary and selectively logged forests.

Estimating the amount of secondary forest and selectively logged forest to be protected from further palm oil expansion is subject to considerable uncertainty. In the case of RSPO member oil palm growers, an HCV assessment must be undertaken in order to determine whether the forest has sufficient ecological value to warrant protection from development (RSPO, 2013). In addition, a methodology for the definition of HCS forest is being developed by an international research team which will add further science-based tools to define the limits of expansion and conservation (High Carbon Stock Study, 2014). In theory, adherence to either the RSPO framework for sustainable palm oil or commitment to no deforestation via protection of HCV or HSV will protect a (currently unknown) proportion of the existing amount of secondary forests in the future. Secondary and selectively logged forests in Indonesia and Malaysia still retain high biodiversity and provide other ecosystem services, including carbon sequestration and storage (Gibson et al., 2011) and therefore the total area

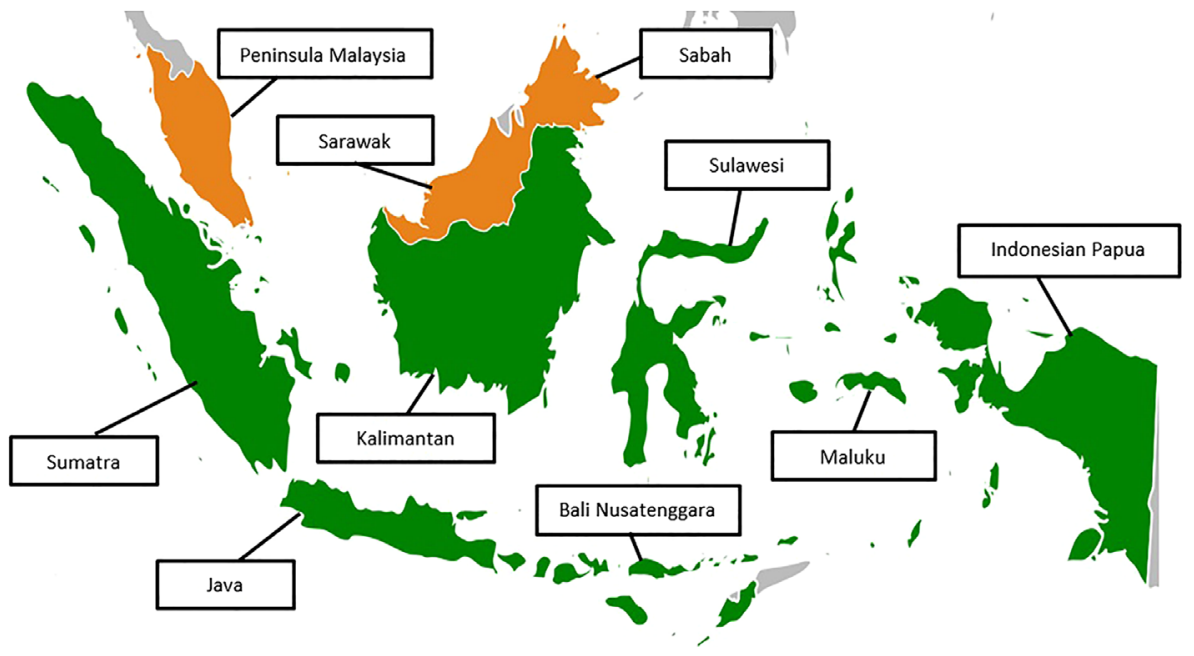

Figure 3. Land types and areas (Mha) in Indonesia and Malaysia affected by palm oil corporate policy initiatives. 
of secondary forests-via HCV and HCS assessments—could be significant. However, regardless of the new definitions and methodologies developed for either HCS or HCV, whilst RSPO membership and compliance with RSPO standards remains low and commitments to no deforestation are not widespread, deforestation of secondary forest will almost certainly continue. In cases where non-RSPO palm oil growers are looking to expand on forested land, such companies will align with less environmentally stringent policy prescriptions of state planning authorities.

\section{Conclusion}

Land use policy and practice in Malaysia and Indonesia has reached a critical juncture. The serious haze episodes as experienced in 2013, 2014 and again in 2015 raised public awareness of the chronic problem of unsustainable land use practices. Failure to effectively address the causes of trans-boundary haze will bring yet further pressure to decision-makers and stakeholders associated with landscape change across Southeast Asia. Focusing on national, international and corporate palm oil policy initiatives in Malaysia and Indonesia, it has been shown that governments and corporations are developing a convergent policy narrative focusing on a sustainability agenda-one that aims to expand palm oil on degraded or previously converted land whilst retaining areas of high ecological value. The article has also identified the potential land types, areas and geographies affected by the recent corporate sustainability policy commitments. The areas affected include approximately 50.5 Mha of primary forests, $68.7 \mathrm{Mha}$ of secondary and selectively logged forests and 10.5 Mha of peatlands in both countries with the largest concentrations found in the Indonesian provinces of Indonesia Papua, Sulawesi, Sumatra and Kalimantan. These areas not only represent the largest potential environmental benefit from the palm oil corporate sustainability commitments, but also the areas with the greatest potential for deforestation and unsustainable expansion of palm oil.

This article suggests there is a diffusion of sustainability policy amongst the largest companies on the issues of deforestation and planting on peatlands, but to a far lesser extent amongst small- and medium-sized companies. Despite the prospect of more frequent dry periods and haze episodes in the future, a widespread diffusion of policy amongst medium and small planters will likely be resisted. Therefore, case-specific interventions to address the particular needs of this group will be critical in slowing further widespread environmental degradation in the future.

Despite the positive policy developments, national, international and corporate policy initiatives alone are unlikely to prevent unsustainable expansion from occurring in the future. The limitations of current national and provincial regulatory frameworks, and enforcement capabilities, as well as the complex web of political, social and economic factors that drive land use change will act as barriers to further sustainability gains. Furthermore, the recent groundswell in sustainability policy commitments in the corporate sector reflects the position of only a small number of companies. Similarly, whilst membership of the industry's leading sustainability initiative, RSPO, remains low, unsustainable expansion strategies are likely to remain the 'business as usual' approach.

Many questions remain regarding how the government and related stakeholders will take the emerging sustainability agenda on land use practice forward. For example, how can national and provincial policy-makers draft policies that address concerns of unsustainable landscape change whilst simultaneously appeasing political and economic agendas? How will the 'innovator' companies enforce their new policy pledges across complex and multifaceted supply chains? What factors can facilitate the diffusion of sustainability policy amongst the medium and small growers? Are there alternative economies or sources of income to support such stakeholders in the case of conservation of forest and peatlands? Finally, looking beyond Southeast Asia, will palm oil companies, including those from Southeast Asia, enforce the same commitments to sustainability in the frontier geographies of West Africa and Latin America? Studying the policy developments related to palm oil expansion not only provides learning on the manifestations of policy diffusion and land use policy and practice in Malaysia and Indonesia but can contribute to wider debates on land use change in geographies beyond Southeast Asia. 


\section{Notes}

1. 'Singapore Dialogue on Sustainable World Resources. Environment and Growth: Conflict or Convergence' organised by the Singapore Institute of International Affairs (SIIA), 20 May 2014.

2. The definition of 'forest cover' has varied interpretations. In Malaysia, whilst areas under oil palm, cocoa and other agricultural crops are frequently regarded as agricultural plantations, areas planted with forest tree species such as pines, Acacia mangium, Gmelina arborea, and rubber are known as forest plantations. They fall under the classification of forest since their end products feed the timber industry.

3. There has been recent evidence of the diffusion of policy change into the Indonesian pulp and paper industry, which, like the palm oil sector, has been implicated in forest loss, peatland development and high GHG emissions. In 2013, Asia Pulp and Paper Group (APP), one of the world's largest producers of pulp and paper, announced their Forest Conservation Policy which heralded an immediate and permanent cessation of natural forest clearance across its supply chain.

\section{Disclosure statement}

No potential conflict of interest was reported by the authors.

\section{ORCID}

Rory Padfield (iD http://orcid.org/0000-0002-1659-6932

\section{References}

Butler, R. A., \& Laurance, W. F. (2009). Is oil palm the next emerging threat to the Amazon? Tropical Conservation Science, 2, 1-10.

Centre for International Forestry Research (CIFOR). (2013). Q\&A on fires and haze in Southeast Asia. Retrieved April 14, 2014, from http://blog.cifor.org/17591/qa-on-fires-and-haze-in-southeast-asia\#.U14PdvmSyNE

Choo, Y. M., Muhamad, H., Hashim, Z., Subramaniam, V., Puah, C. W., \& Tan, Y. (2011). Determination of GHG contributions by subsystems in the oil palm supply chain using the LCA approach. The International Journal of Life Cycle Assessment, $16,669-681$.

Christmann, P., \& Taylor, G. (2001). Globalization and the environment: Determinants of firm self-regulation in China. Journal of International Business Studies, 32, 439-458.

Cramb, R., \& Sujang, P. (2011). 'Shifting ground': Renegotiating land rights and rural livelihoods in Sarawak, Malaysia. Asia Pacific Viewpoint, 52, 136-147.

Emilia, S. (2014). Choking haze. Retrieved May 1, 2014, from http://www.thejakartapost.com/news/2014/03/18/chokinghaze.html

Fitzherbert, E. B., Struebig, M. J., Morel, A., Danielsen, F., Brühl, C. A., Donald, P. F., \& Phalan, B. (2008). How will oil palm expansion affect biodiversity? Trends in Ecology \& Evolution, 23, 538-545.

Food and Agriculture Organisation (FAO). (2011). Retrieved June 23, 2014, from http://faostat3.fao.org/faostat-gateway/ go/to/home/E

Forsyth, T. (2014). Public concerns about transboundary haze: A comparison of Indonesia, Singapore, and Malaysia. Global Environmental Change, 25, 76-86. doi:http://dx.doi.org/10.1016/j.gloenvcha.2014.01.013

Foster, W. A., Snaddon, J. L., Turner, E. C., Fayle, T. M., Cockerill, T. D., Farnon Ellwood, M. D., ... Yusah, K. M. (2011). Establishing the evidence base for maintaining biodiversity and ecosystem function in the oil palm landscapes of South East Asia. Philosophical Transactions of the Royal Society B, 366. Retrieved from http://rstb.royalsocietypublishing.org/ content/366/1582.toc

Gibson, L., Lee, T., Koh, L., Brook, B., Gardner, T., Barlow, J., ... Sodhi, N. (2011). Primary forests are irreplaceable for sustaining tropical biodiversity. Nature, 478, 378-381.

Golden Agri-Resources (GAR). (2012). Sustainability Report 2012. Retrieved from http://www.goldenagri.com.sg/ sustainability_report_2012.php

Goldstein, J. (in press). Knowing the subterranean: Land grabbing, oil palm, and divergent expertise in Indonesia's peat soil. Environment and Planning A. doi:http://dx.doi.org/10.1177/0308518X15599787

Government of Indonesia. (2011). National action plan for GHG emissions reduction. The Presidential Regulation of the Republic of Indonesia. Law No. 61/2011.

Government of Indonesia. (2013a). Law on prevention and eradication of forest destruction. Law No. 18/2013.

Government of Indonesia. (2013b). Statistics 2013. Ministry of Forestry. Retrieved November 24, 2014, from http://www. dephut.go.id/index.php/news/statistik_kehutanan 
Government of Malaysia. (2012). Forestry Department Peninsula Malaysia. Retrieved November 16, 2014, from http://www. forestry.gov.my/index.php/en/pusat-sumber2/arkib-jpsm-3/perangkaan-perhutanan-2

Government of Malaysia. (2014a). Fifth national report to the convention on biological diversity. Ministry of Natural Resources \& Environment (NRE). Putra Jaya.

Government of Malaysia. (2014b). National Commodities Policy (NCP) 2011-2020. Putra Jaya.

Greenpeace. (2013a). You did it! Palm oil giant commits to no deforestation. Retrieved May 1, 2014, from http://www. greenpeace.org/international/en/news/Blogs/makingwaves/palm-oil-giant-Wilmar-commits-no-deforestation/ blog/47623/

Greenpeace. (2013b). Certifying destruction: Why consumer companies need to go beyond the RSPO to stop forest destruction. Retrieved May 1, 2014, from http://www.greenpeace.de/files/publications/rspo-certifying-destruction.pdf

Gunes-Ayata, A. (1994). Clientelism: Premodern, modern, postmodern. In L. Roniger \& A. Gunes-Ayata (Eds.), Democracy, clientelism, and civil society (pp. 17-26). London: Lynne Rienner.

Hansen, S., Olsen, S., \& Ujang, Z. (2014). Carbon balance impacts of land use changes related to the life cycle of Malaysian palm oil-derived biodiesel. The International Journal of Life Cycle Assessment, 19, 558-566.

Hansen, S., Padfield, R., Syayuti, K., Evers, S., Zakariah, Z., \& Mastura, S. (2015). Trends in global palm oil sustainability research. Journal of Cleaner Production, 100, 140-149.

High Carbon Stock Study. (2014). Homepage. Retrieved November 15, 2014, from http://www.carbonstockstudy.com/Home

Hooijer, A., Page, S. E., Canadell, J. G., Silvius, M., Kwadijk, J., Wösten, H., \& Jauhiainen, J. (2010). Current and future $\mathrm{CO}_{2}$ emissions from drained peatlands in Southeast Asia. Biogeosciences, 7, 1505-1514.

ISPO. (2014). ISPO Welcome. Retrieved February 23, 2015, from http://www.ispo-org.or.id/index.php?lang=en

Joosten, H., Tapio-Biström, M. L., Tol, S. (2012). Peatlands-guidance for climate change mitigation through conservation, rehabilitation and sustainable use. Retrieved November 24, 2014, from http://www.fao.org/docrep/015/an762e/an762e.pdf

Koh, L. P., \& Ghazoul, J. (2008). Biofuels, biodiversity, and people: Understanding the conflicts and finding opportunities. Biological Conservation, 141, 2450-2460.

Lucas, C. (2011, June 1). How palm oil jeopardises global efforts to reduce emissions. Retrieved November 15, 2014, from http://www.theguardian.com/environment/blog/2011/jun/01/palm-oil-global-emissions

Malaysian Palm Oil Board (MPOB). (2011). Sustainable palm oil. Retrieved June 24, 2014, from http://www.palmoilworld. org/sustainability.html

Malaysian Palm Oil Council (MPOC). (2014). Timely reminder to oil palm planters in Sarawak. Retrieved May 25, 2014, from http://www.mpoc.org.my/Timely_Reminder_to_Oil_Palm_Planters_in_Sarawak_\%E2\%80\%94_SOPPOA_aspx

Marin-Burgos, V., Clancy, J., \& Lovett, J. (in press). Contesting legitimacy of voluntary sustainability certification schemes: Valuation languages and power asymmetries in the roundtable on sustainable palm oil in Colombia. Ecological Economics, 117, 303-313.

Marlier, M., DeFries, R., Kim, P., Koplitz, S., Jacob, D., Mickley, L., \& Myers, S. (2015). Fire emissions and regional air quality impacts from fires in oil palm, timber, and logging concessions in Indonesia. Environmental Research Letters, 10, 085005.

McCarthy, J., \& Cramb, R. (2009). Policy narratives, landholder engagement, and oil palm expansion on the Malaysian and Indonesian frontiers. Geographical Journal, 175, 112-123.

Miettinen, J., Wang, J., Hooijer, A., \& Liew, S. (2011). Peatland conversion and degradation processes in insular Southeast Malaysia: A case study in Jambi, Indonesia. Land Degradation and Development, 22, 1002-1130.

Miettinen, J., Hooijer, A., Shi, C., Tollenaar, D., Vernimmen, R., Liew, S. C., ... Page, S. E. (2012). Extent of industrial plantations on Southeast Asian peatlands in 2010 with analysis of historical expansion and future projections. Global Change Biology-Bioenergy, 4, 908-918.

Moore, S., Evans, C., Page, S., Garnett, M., Jones, T., Freeman, C., ... Gauci, V. (2013). Deep instability of deforested tropical peatlands revealed by fluvial organic carbon fluxes. Nature, 493, 660-663.

MPOB. (2013). Malaysian palm oil statistics 2012. Putra Jaya: Ministry of Plantation Industries \& Commodities.

MSPO. (2013). MS 2530-4:2013 Malaysian sustainable palm oil (MSPO) part 4: General principles for palm oil mills ICS: 65.020.20. Putra Jaya: Department of Standards.

Murdiyarso, D., Dewi, S., Lawrence, D., \& Seymour, F. (2011). Indonesia's forest moratorium: A stepping stone to better forest governance? Center for International Forestry Research (CIFOR). Bogor.

Oil World. (2009). Retrieved April 22, 2014, from http://www.oilworld.biz/app.php?fid=1000\&fpar=0\&isSSL=0\&aps= 0\&blub=00bf172bb40cde9e19d029f9be854620

Padfield, R., \& Hansen,S. (2010, November 1). Striking a balance in the palm oil debate in: The environmentalist (Nov Ed.). Ashford, UK: Institute for Environmental Management and Assessment (IEMA). Retrieved from http://www. environmentalistonline.com/article/striking-balance-palm-oil-debate

Padfield, R., Waldron, S., Drew, S., Papargyropoulou, E., Kumaran, S., Page, S., ... Tham, M. (2014). Research agendas for the sustainable management of tropical peatland in Malaysia. Environmental Conservation, 42, 73-83. doi:http://dx.doi. org/10.1017/S0376892914000034

Page, S. E., Rieley, J. O., \& Banks, C. J. (2011). Global and regional importance of the tropical peatland carbon pool. Global Change Biology, 17, 798-818.

Papargyropoulou, E., Padfield, R., Harrison, O., \& Preece, C. (2012). The rise of sustainability services for the built environment in Malaysia. Sustainable Cities and Society, 5, 44-51. 
Pierce, F. (2008, November 6). The slippery business of palm oil. The Guardian. Retrieved June 4, 2014, from http://www. theguardian.com/environment/2008/nov/06/1

Poynton, S. (2014). Wilmar's'no deforestation' goal could revolutionise food production. Retrieved May 5, 2014, from http:// www.theguardian.com/sustainable-business/wilmar-no-deforestation-commitment-food-production

Pye, O., Daud, R., Harmono, Y., \& Tatat. (2012). Precarious lives: Transnational biographies of migrant oil palm workers. Asia Pacific Viewpoint, 53, 330-342.

Rogers, E. (1962). Diffusion of innovations. Glencoe: Free Press.

RSPO. (2006, February 22). Smallholder task force: Minutes of first meeting. Kuala Lumpur: RSPO.

RSPO. (2012). RSPO worldwide impact. Retrieved June 10, 2014, from http://www.rspo.org/en/RSPO_Worldwide_Impact

RSPO. (2013). Principles and criteria for the production of sustainable palm Oil 2013. Retrieved May 22, 2014, from http://www. rspo.org/file/RSPO\%20P\&C2013_with\%20Major\%20Indicators_Endorsed\%20by\%20BOG_FINAL_A5_25thApril2014.pdf

Sabah Forestry Department. (2012). Annual report 2012: Forest resource management. Retrieved November 24, 2014, from http://www.forest.sabah.gov.my/images/pdf/publications/AR2012/Chap18.pdf

Sarawak Forest Department. (2014). Types and categories of Sarawak's forests. Retrieved November 24, 2014, http://www. forestry.sarawak.gov.my/modules/web/pages.php?mod=webpage\&sub=page\&id=593\&menu_id=0\&sub_id=160

Sarawak Report. (2014). Sarawak oil palm owners show true colours. Retrieved June 2, 2014, from http://www.sarawakreport. org/2014/01/sarawak-oil-palm-owners-show-true-colours-and-let-taibs-cat-out-of-the-bag/

Schouten, G., \& Glasbergen, P. (2011). Creating legitimacy in global private governance: The case of the roundtable on sustainable palm oil. Ecological Economics, 70, 1891-1899.

Schouten, G., \& Glasbergen, P. (2012). Private multi-stakeholder governance in the agricultural market place: An analysis of legitimization processes of the roundtables on sustainable palm oil and responsible soy. International Food and Agribusiness Management Review, 15, 63-88.

Sime Darby. (2016). Best Practices. Retrieved April 11, 2016, from http://www.simedarby.com/sustainability/deliveringsustainable-development/continuous-improvements/best-practices

Singapore Institute of International Affairs. (2014). From the haze to resources: Mapping a path to sustainability. Special Report. March 2014. Retrieved November 15, 2015, from http://www.siiaonline.org/page/PublicationDetails/id/117/ ArticleCategoryld/3\#.Vws9nPI95dg

Sloan, S. (2014). Indonesia's moratorium on new forest licenses: An update. Land Use Policy, 38, 37-40.

Stanford, D. (2014). Kellogg to stop buying deforested palm oil amid pressure. Retrieved May 27, 2014, from http://www. bloomberg.com/news/2014-02-14/kellogg-to-stop-using-deforested-palm-oil-by-2016-amid-pressure.html

Sutton, K. (2001). Agribusiness on a grand scale - Felda's sahabat complex in East Malaysia. Singapore Journal of Tropical Geography, 22, 90-105.

Swaffield, S., \& Primdahl, J. (2014). Editorial: Pathways towards local scale policy integration in agricultural landscapes. Landscape Research, 39, 101-106.

Tacconi, L., Jotzo, F., \& Grafton, R. (2007, March). Local causes, regional co-operation and global financing for environmental problems: The case of Southeast Asian haze pollution. International Environmental Agreements: Politics, Law and Economics, 8, 1-16.

Takakai, F., Morishita, T., Hashidoko, Y., Darung, U., Kuramochi, K., Dohong, S., ... Hatano, R. (2006). Effects of agricultural land-use change and forest fires on $\mathrm{N}_{2} \mathrm{O}$ emission from tropical peatlands, Central Kalimantan, Indonesia. Soil Science Plant Nutrition, 52, 662-674.

The Star. (2014). Couple charged with five counts of illegal logging. Retrieved May 23, 2014, from http://www.thestar.com. my/News/Nation/2014/02/12/Couple-charged-with-five-logging-counts/

United Nations Development Programme (UNDP). (2012). UNDP and Ministry of Agriculture launch Indonesia Sustainable Palm Oil (SPO) Initiative. Retrieved May 22, 2014, from http://www.undp.or.id/press/view.asp?FileID=201212201\&lang=en

Varkkey, H. (2012). Patronage politics as a driver of economic regionalisation: The Indonesian oil palm sector and transboundary haze. Asia Pacific Viewpoint, 53, 314-329.

Vermeulen, S., \& Goad, N. (2006). Towards better practice in smallholder palm oil production. Natural Resource Issues Series No. 5. International Institute for Environment and Development. London.

von Geibler, J. (2013). Market-based governance for sustainability in value chains: Conditions for successful standard setting in the palm oil sector. Journal of Cleaner Production, 56, 39-53.

Wicke, B., Sikkema, R., Dornburg, V., \& Faaij, A. (2011). Exploring land use changes and the role of palm oil production in Indonesia and Malaysia. Land Use Policy, 28, 193-206.

Wilmar International. (2013, December 5). No deforestation, no peat, no exploitation policy. Retrieved May 25, 2014, from http:// www.wilmar-international.com/wp-content/uploads/2012/11/No-Deforestation-No-Peat-No-Exploitation-Policy.pdf

Xiao, Z., Zhang, Y., Hong, S., Bi, X., Jiao, L., Feng, Y., \& Wang, Y. (2011). Estimation of the main factors influencing haze, based on a long-term monitoring campaign in Hangzhou, China. Aerosol and Air Quality Research, 11, 873-882.

Zhu, Q., Cordeiro, J., \& Sarkis, J. (2012). International and domestic pressures and responses of Chinese firms to greening. Ecological Economics, 83, 144-153. 